UDC 620.175.2:669.15

\title{
INCREASING THE CORROSION RESISTANCE OF WELDED JOINTS OF HEAT-RESISTANT NICKEL ALLOY WITH STEEL
}

\author{
V.I. Bolshakov', O.V. Kalinin ${ }^{1}$, N.E. Kalinina ${ }^{2}$, D.B. Hlushkova ${ }^{3}$, \\ O.I. Voronkov, Y.V. Ryzhkov ${ }^{3}$, A.I. Stepanyuk ${ }^{3}$ \\ ${ }^{1}$ Prydniprovska State Academy of Civil Engineering and Architecture, Dnipro, Ukraine; \\ ${ }^{2}$ Oles Honchar Dnipro National University, Dnipro, Ukraine \\ E-mail: kalinina.dnu@gmail.com; \\ ${ }^{3}$ Kharkiv National Automobile and Highway University, Kharkiv, Ukraine \\ E-mail: diana@khadi.kharkov.ua
}

For parts and assemblies of a turbopump unit (TPU) and a liquid rocket engine, welded joints of steel and heatresistant alloys are used. Considering that the search for replacements by several materials at once, the study of their mutual compatibility in a product takes considerable time and money. Therefore, it would be better to replace it with one alloy, and the unification of the material used allowed the structure to work as a whole. After exploring various options, the substitutes for research were selected inconel 718.

\section{INTRODUCTION}

The main operational properties of parts and components of turbopump assembly (TPU) are heat resistance and corrosion resistance. If the first requirement is achieved by the selection of materials, then the second depends on further processing.

Thermal effects during welding and heat treatment affect the structure of the alloy, changing its operational properties. Therefore, the paper investigated the influence of thermal effects on the corrosion resistance of welded joints of the main combinations of materials used in the manufacture of missile-carrying aircrafts. Since majority of the parts and assemblies of TPU are both soldered and welded in various sequences, the case of band soldering after welding with corrosion-resistant steel is considered in the paper. Heat-resistant alloys are used for the manufacture of many parts of gas turbines in rocket and missile engineering and jet aviation, industry gas turbines, for pumping oil and gas products, for hydrogenation of fuel in metallurgical furnaces and in many other installations [1].

This paper was performed in order to study the thermal effects during soldering on a welded seam and to simulate the conditions for manufacturing real components.

\section{PROBLEM STATUS OVERVIEW}

Corrosion is an involuntary redox process of metals and alloys destruction due to interaction with the environment. When multicomponent alloys come into contact with an electrolyte (which can be $\mathrm{H}_{2} \mathrm{O}$ adsorbed from air, since it usually contains ions of dissolved substances), many microgalvanic pairs arise on the metal surface. In these pairs, the atoms of the more active metal (usually $\mathrm{Fe}$ ) play the role of the anode, while the atoms of the less active metal play the role of the cathode. At the cathode, the process of reduction of $\mathrm{O}_{2}$ molecules in neutral and alkaline media or $\mathrm{H}^{+}$-ions in an acidic medium is underway. At the anode, the oxidation of the metal atoms of which the anode consists is performed, along with the formation of $\mathrm{Me}_{\mathrm{n}}^{+}$-cations.
The latter pass into the electrolyte (dissolution of the anode) and combine with $\mathrm{OH}$-ions in order to form hydroxide $\mathrm{Me}(\mathrm{OH}) \mathrm{n}$ and other products. As a result, the metal that plays the role of the anode is destroyed. The rate of electrochemical corrosion is the greater, the further apart from each other the metals are located in the series of voltages, and the higher the ambient temperature [2].

Nickel has aface-centered cubic lattice similar to the Fey lattice, therefore nickel alloying expands the austenite field (Fig. 1).

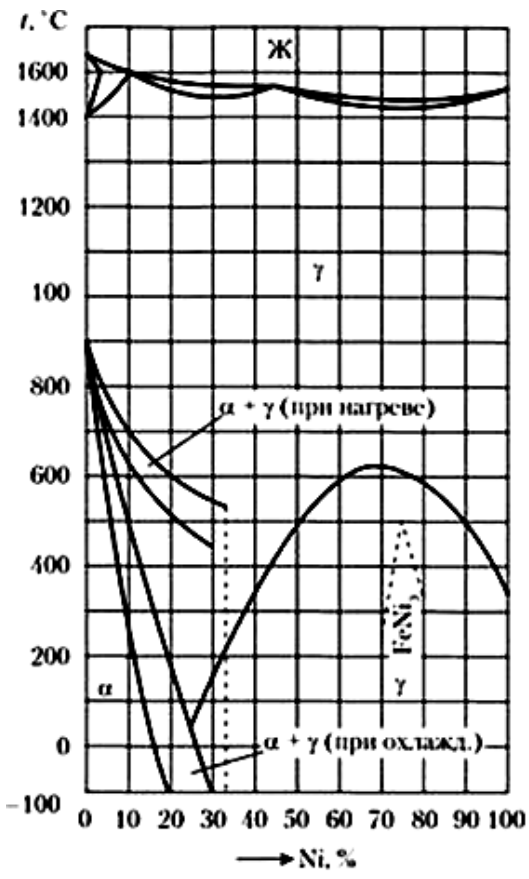

Fig. 1. State diagram of the Fe-Ni system [2]

The most widely used chromium-nickel steels are 12X18H9 and 12X18H9T. The structure of these steels is austenite both at room temperature and when heated, that is, they do not undergo polymorphic transformation. Products made of these steels are subjected to heat treatment, but not for the purpose of strengthening 
(this is impossible, since no recrystallization occurs when the temperature changes), but in order to increase the corrosion resistance by enriching the solid solution with chromium. In the presence of carbon, chromium carbides are present in the steel structure. This means that not all the chromium is in solid solution. Hardening from a temperature of $\sim 1000{ }^{\circ} \mathrm{C}$ with cooling in water allows to dissolve chromium carbides in austenite and prevent their precipitation during rapid cooling [3].

\section{MATERIALS AND METHODS}

The materials for the study were: a heat-resistant alloy of the austenitic class inconel 718 of the Fe-Cr-Ni system and corrosion-resistant steels $12 \mathrm{X} 18 \mathrm{H} 10 \mathrm{~T}$ and SLS 316L (Table 1).

Inconel 718 is a heat-resistant nickel alloy of the $\mathrm{Fe}-\mathrm{Cr}-\mathrm{Ni}$ system and is used in rocket engineering for the manufacture of jackets for rocket combustion chambers, parts for turbopump units and other critical products. This alloy is used in the following temperature range: from -252.8 to $704.4{ }^{\circ} \mathrm{C}$, it is resistant to the temperature $+980{ }^{\circ} \mathrm{C}$ in chemically active gas environments.

After welding, blank samples were sent for soldering according to the manufacturing process.

Soldering was performed in 2 modes:

- heating up to $(950 \pm 10){ }^{\circ} \mathrm{C}$, holding for $30 \mathrm{~min}$ from the moment of loading into the furnace, cooling to $300{ }^{\circ} \mathrm{C}$ - in the furnace, then - in air;

- heating up to $(1200 \pm 10){ }^{\circ} \mathrm{C}$, holding for $20 \mathrm{~min}$ from the moment of loading into the furnace, cooling to $300{ }^{\circ} \mathrm{C}$ - with the furnace, then - in air $[4,5]$.

Steel $316 \mathrm{~L}$ is a structural cryogenic austenitic steel. This steel is resistant to corrosion in aggressive environments, as well as to most external influences. Steel $316 \mathrm{~L}$ has the property of maintaining the integrity of the structure when temperatures rise and fall.
The list of the studied materials and their chemical composition are given in Table 1.

Works, testing and research were performed on industrial equipment. During control, testing and research, tools and methods corresponding to GOST or OST, used for heat-resistant alloys, were used [6, 7].

Heat treatment was performed in a thermal silicon carbide furnace. Simulation of soldering with $\Gamma 70 \mathrm{HX}$ solder was performed with the transition of a full soldering mode according to a typical technical process, the modes of which are indicated below. The welding was performed on the "SAB-15" welding machine.

\section{RESULTS AND ITS DISCUSSION}

Preparation for welding. Before welding, each workpiece underwent visual inspection for the presence of oxidizing films, hammer marks, as well as geometry control and magnet control.

According to the standard, immediately before welding, each welded edge is cleaned from oxidizing films after heat treatment and degreased with a Nefras-type solvent.

Welding technology. The welded assemblies were welded by argon-arc welding, Argon consumption: for protection $15 \mathrm{l} / \mathrm{min}$, for blowing $5 \mathrm{l} / \mathrm{min}$.

When welding in an atmosphere of shielding gases argon and helium were used in the the following composition: volume fraction of argon $-99.90 \%$, oxygen $0.005 \%$, nitrogen $-0.10 \%$, water vapor at $760 \mathrm{~mm} \mathrm{Hg}-$ $0.03 \mathrm{~g} / \mathrm{m}^{3}$.

Weld seam finishing. In order to remove the oxidizing film and colors of changing, the surface of the weld and heat-affected zone was processed to a roughness parameter of $\mathrm{Rz} 40$.

All welded joints have passed X-ray inspection for welding defects.

Table 1

Chemical composition of inspected alloys

\begin{tabular}{|c|c|c|c|c|c|c|c|c|c|c|c|c|c|c|c|}
\hline \multirow{2}{*}{ Alloy } & \multirow{2}{*}{$\begin{array}{c}\text { Semi- } \\
\text { finished, } \mathrm{mm}\end{array}$} & \multicolumn{14}{|c|}{ Chemical composition, wt.\% } \\
\hline & & $\mathrm{C}$ & $\mathrm{Mn}$ & $\mathrm{Si}$ & $\mathrm{S}$ & $\mathrm{P}$ & $\mathrm{Cr}$ & $\mathrm{Ni}$ & $\mathrm{Ti}$ & Mo & $\mathrm{W}$ & $\mathrm{V}$ & $\mathrm{Al}$ & $\mathrm{Cu}$ & $\mathrm{Fe}$ \\
\hline \multirow{2}{*}{ Inconel 718} & Sheet 3.17 & $\stackrel{\overbrace{}}{0}$ & $\stackrel{\infty}{0}$ & $\stackrel{\infty}{0}$ & $\begin{array}{l}\overline{8} \\
8 \\
0\end{array}$ & $\begin{array}{l}\infty \\
\stackrel{8}{8} \\
0\end{array}$ & $\underset{\sim}{\stackrel{ \pm}{\Lambda}}$ & $\begin{array}{l}n \\
\tilde{n} \\
\tilde{n}\end{array}$ & ă & बे & 1 & $\begin{array}{l}\text { oे } \\
0 \\
\dot{1} \\
\infty\end{array}$ & $\bar{n}$ & $\hat{0}$ & $\stackrel{n}{n}$ \\
\hline & $\begin{array}{l}\text { Welded wire } \\
\varnothing 1.6\end{array}$ & $\begin{array}{l}\text { t. } \\
0\end{array}$ & $\stackrel{0}{0}$ & $\stackrel{0}{0}$ & $\stackrel{8}{8}$ & $\stackrel{\infty}{8}$ & $\begin{array}{l}n \\
\infty \\
\infty\end{array}$ & $\begin{array}{l}\underset{+}{+} \\
\text { in }\end{array}$ & $\stackrel{\infty}{\stackrel{\infty}{0}}$ & $\begin{array}{l}\infty \\
\infty \\
i\end{array}$ & 1 & $\begin{array}{l}+ \\
8 \\
0 \\
\dot{0}\end{array}$ & $\stackrel{\infty}{n}$ & $=$ & $\stackrel{\infty}{\stackrel{\infty}{\leftrightarrows}}$ \\
\hline $12 \mathrm{X} 18 \mathrm{H} 10 \mathrm{~T}$ & Sheet 3.0 & $\stackrel{2}{0}$ & ñ & ñ? & §̊. & ठे. & $\stackrel{\substack{n\\
}}{=}$ & $\stackrel{n}{a}$ & m & $\overrightarrow{0}$ & ڤิ & ठे. & 1 & กิ & 芯 \\
\hline $316 \mathrm{~L}$ & Sheet 3.0 & $\stackrel{\overbrace{}}{0}$ & $\stackrel{0}{i}$ & $\stackrel{\circ}{-}$ & $\stackrel{0}{0}$ & $\stackrel{n}{q}$ & $\stackrel{0}{0}$ & $\begin{array}{l}n \\
\dot{\Xi}\end{array}$ & $n$ & $\vec{m}$ & ฮి & 1 & 1 & 1 & 吾 \\
\hline
\end{tabular}

\section{DETERMINATION OF RESISTANCE TO} INTERCRYSTALLINE CORROSION (ICC)

Investigation of welded specimens of the inconel 718-stainless steel alloy for resistance to ICC by the "AM" GOST 6032-89 method was performed from the steel side. The surface of the $316 \mathrm{~L}$ steel in the weld zone was examined as delivered, without surface deburring. The research results are given in Table 2 .

Etching was performed in a reagent with the following composition: water $-1000 \mathrm{~cm}^{3}$, sulfuric acid copper $-130.0 \mathrm{~g}$, sulfuric acid $-120.0 \mathrm{~g}$. It was kept in this solution for 7 days from the moment of immersion at a 
temperature of $(20 \pm 50)^{\circ} \mathrm{C}$. After a lapse of time, the surface is passivated in a $20 \%$ aqueous solution of sodium carbonate and washed with distilled water.

In accordance with the requirements of GOST 6032 89 , the sample is considered resistant if the depth of the
ICC does not exceed $0.03 \mathrm{~mm}$. Increased etching is not a sign of rejection, but indicates the tendency of the material to corrosion (see Table 2).

ICC test results

Table 2

\begin{tabular}{|c|c|c|c|c|}
\hline $\begin{array}{l}\text { Specimen } \\
\text { ref. No. }\end{array}$ & Material & $\begin{array}{l}\text { Heat treatment } \\
\text { mode }\end{array}$ & ICC depth, mm & Result \\
\hline 132 & \multirow{2}{*}{$\begin{array}{l}\text { STS 316L - } \\
\text { inconel } 718\end{array}$} & $\begin{array}{c}\text { Soldering at } 950{ }^{\circ} \mathrm{C} \\
+ \text { aging }\end{array}$ & \multirow{2}{*}{$\begin{array}{c}\text { No ICC } \\
\text { (increased etching per depth up to } \\
0.33 \mathrm{~mm} \text { ) }\end{array}$} & \multirow[b]{2}{*}{ Resistant } \\
\hline 133 & & $\begin{array}{c}\text { Soldering at } \\
1200{ }^{\circ} \mathrm{C}+\text { aging }\end{array}$ & & \\
\hline 151 & \multirow{3}{*}{$\begin{array}{l}12 \mathrm{X} 18 \mathrm{H} 10 \mathrm{~T}- \\
\text { inconel } 718\end{array}$} & & 0.24 & \multirow{3}{*}{$\begin{array}{l}\text { Non- } \\
\text { resistant }\end{array}$} \\
\hline 141 & & $1210^{\circ} \mathrm{C}+$ aging & $\begin{array}{l}0.17 \text { (increased etching per depth up to } \\
0.23 \mathrm{~mm} \text { ) }\end{array}$ & \\
\hline 2 & & $\begin{array}{c}\text { Soldering at } 950{ }^{\circ} \mathrm{C} \\
+ \text { aging }\end{array}$ & $\begin{array}{l}0.07 \text { (increased etching per depth up to } \\
0.14 \mathrm{~mm} \text { ) }\end{array}$ & \\
\hline
\end{tabular}

External inspection and metallographic examination were performed. It was found that the surface of the specimens from the outlet side is rough with the presence of recesses and buckles of aprolonged and rounded shape, the other side after mechanical treatment is smooth.

The micro-examination of the cross-sections of the investigated samples ref. No. 132, 133 did not reveal ICC. An increased etching of grains was observed from the surface to a depth of $0.33 \mathrm{~mm}$ (Fig. 2).

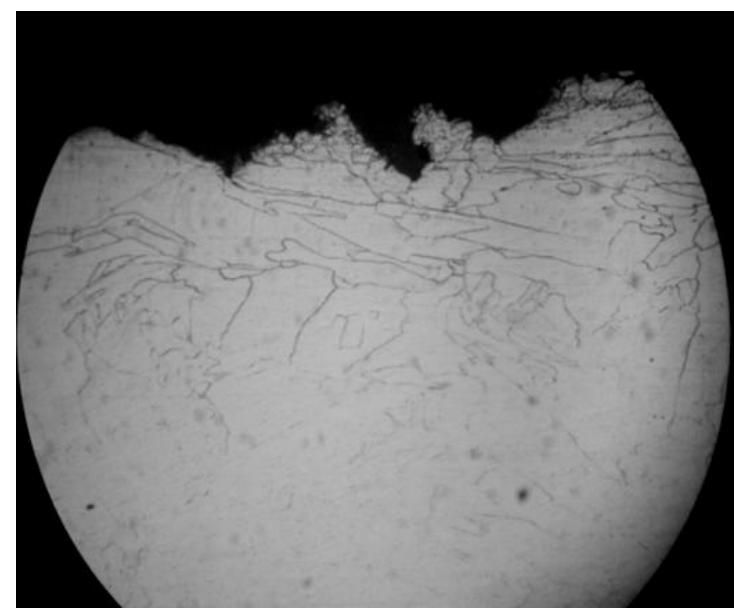

Fig. 2. Increased etching of grains on the specimen surface from the side of $316 \mathrm{~L}$ steel, $x 200$

ICC on $12 \mathrm{X} 18 \mathrm{H} 10 \mathrm{~T}$ steel specimens is shown in Fig. 3.

When examining the specimens after soldering at $1200{ }^{\circ} \mathrm{C}$, it was found that the specimens are less resistant to ICC than those soldered at a temperature of $950{ }^{\circ} \mathrm{C}$.

The increased etching of the grains of 316L steel indicates the tendency of the alloy to ICC, but is not its definition.

The figure clearly shows the zones of corrosion pitting of grain, which reveals the non-resistance of steel $12 \mathrm{X} 18 \mathrm{H} 10 \mathrm{~T}$ to ICC after soldering at a temperature of $1200{ }^{\circ} \mathrm{C}$.

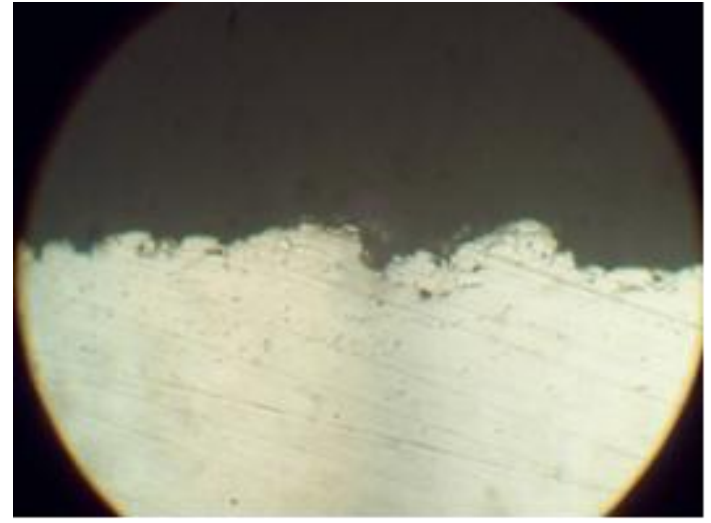

Fig. 3. ICC on steel specimens 12X18H10T, x200

\section{CONCLUSIONS}

After high-temperature heating against ICC, the resistance of both steels decreases.

The inspection of welded specimens of inconel 718stainless steels for resistance to ICC showed that welded joints of the alloy with steel 12X18H10T and steel 316L after heating during soldering and aging in corrosive environments are not preferable to apply.

The inspection of welded specimens of inconel 718stainless steel alloy for resistance to ICC, showed that it is not preferable to use welded joints of inconel 718 alloy with steel $12 \mathrm{X} 18 \mathrm{H} 10 \mathrm{~T}$ and steel $316 \mathrm{~L}$ after hightemperature heating during soldering.

The recommended mode of soldering is heating up to $(950 \pm 10){ }^{\circ} \mathrm{C}$, holding for $30 \mathrm{~min}$ from the moment of loading into the furnace, cooling to $300{ }^{\circ} \mathrm{C}-$ in the furnace, then in air, it is most effective for increasing the corrosion resistance of welded joints.

\section{REFERENCES}

1. D.B. Glushkova, V.I. Bol'shakov. Povy'shenie dolgovechnosti otvetstvenny'h detaley stroitel'ny'h mashin: Monogr. Har'kov: "Cifroprint", 2015, 236 p. (in Russian).

2. V.P. Kuznecov, V.P. Lesnikov, N.A. Popov. Struktura i svoystva monokristallicheskih jaroprochny'h nikelevy'h splavov: Uchebnoe posobie. Ekaterinburg: Izdatel'stvo Ural. Un., 2016, 160 p. (in Russian). 
3. A.V. Logunov, Yu.N. Shmotin, I.A. Lesch'enko, B.Yu. Starkov. Modelirovanie i razrabotka novy'h jaroprochny'h splavov. Part 1 // Dvigatel'. 2013, N 5(89), p. 24-27 (in Russian).

4. G.A. Merkulova. Metallovedenie i termicheskaya obrabotka cvetny'h splavov: Uchebnoe posobie. Krasnoyarsk: "Sib. feder. Un"., 2008, 312 p. (in Russian).

5. N.E. Kalinina, O.D. Hrinchenko, A.I. Voronkov, et al. Hardening of leading edges of turbine blades by electrospark alloying // Problems of Atomic Science and Technology. Series "The Physics of Radiation Effect and Radiation Materials Science”. 2019, N 2(120), p. 151-154.

6. D.B. Hlushkova, Y.V. Ryzhkov, L.L. Kostina, S.V. Demchenko. Increase of wear resistance of the critical parts of hydraulic hammer by means of ionplasma treatment // Problems of Atomic Science and Technology. 2018, N 1(113), p. 181-188.

7. O.G. Ospennikova. Strategiya razvitiya jaroprochnyh splavov i staley special'nogo naznacheniya, zaschitnyh i teplozaschitnyh pokrytiy // Aviacionnye materialy i tehnologii. 2012, N 5, p. 19-35 (in Russian).

\title{
ПОВЫШЕНИЕ КОРРОЗИОННОЙ СТОЙКОСТИ СВАРНЫХ СОЕДИНЕНИЙ ЖАРОПРОЧНОГО НИКЕЛЕВОГО СПЛАВА СО СТАЛЬЮ
}

\author{
В.И. Больиаков, А.В. Калинин, Н.Е. Калинина, Д.Б. Глуикова, А.И. Воронков, \\ Ю.В. Рыжков, А.И. Степанюк
}

\begin{abstract}
Для изготовления деталей и узлов турбонасосного агрегата (ТНА) и жидкостного ракетного двигателя применяются сварные соединения с коррозионно-стойкими сталями и жаропрочными сплавами, требующие разные режимы термической обработки для получения уровня механических свойств, обозначенных в конструкторской документации. Учитывая, что поиск замены сразу нескольких материалов, их отработка в производстве, исследование взаимной сочетаемости при температурно-силовых воздействиях в изделии может занять значительные время и средства, то наилучшей была бы замена на один сплав, а унификация применяемого материала позволила конструкции работать как единое целое и повысила бы технологичность изделий. Изучив разные варианты замены, для исследований был выбран inconel 718.
\end{abstract}

\section{ПІДВИЩЕННЯ КОРОЗІЙНОЇ СТІЙКІСТІ ЗВАРНИХ З'ЄДНАНЬ ЖАРОМІЦНОГО НІКЕЛЕВОГО СПЛАВУ ЗІ СТАЛЛЮ}

\section{В.І. Большаков, О.В. Калінін, Н.С. Калініна, Д.Б. Глушкова, О.І. Воронков, Ю.В. Рижков, А.I. Степанюк}

Для виготовлення деталей і вузлів турбонасосного агрегату (ТНА) і рідинного ракетного двигуна застосовуються зварні з'єднання з корозійно-стійкими сталями і жароміцними сплавами, які вимагають різних режимів термічної обробки для досягнення рівня механічних властивостей, зазначених у конструкторськой документації. 3 огляду на те, що пошук заміни відразу декількох матеріалів, їх відпрацювання у виробництві і дослідження взаємної сполучності при температурно-силових впливах у виробі, може зайняти значний час і кошти, найкращою була б заміна на один сплав, а уніфікація застосовуваного матеріалу дозволила конструкції працювати як єдине ціле, що підвищило б технологічність виробів. Після вивчення різних варіантів заміни, для дослідження було обрано inconel 718. 